\title{
MAKNA KATA KHARIS BERDASARKAN SURAT EFESUS 2:8 DAN IMPLEMENTASINYA DALAM KEHIDUPAN ORANG PERCAYA MASA KINI
}

\author{
Rose Melly Merang \\ sttjaffraymakassar@yahoo.co.id \\ Robi Panggarra \\ sttjaffraymakassar@yahoo.co.id
}

\begin{abstract}
ABSTRAK
Sesuai dengan permasalahan yang ada, maka tujuan penulisan karya ilmiah ini adalah: Pertama, untuk menganalisis dan menafsirkan makna di balik kata kharis berdasarkan Efesus 2:8. Kedua, untuk membahas bagaimana mengimplementasikan kharis dalam kehidupan orang-orang percaya masa kini.

Dalam penulisan penelitian ini, penulis menggunakan metode penelitian naskah Alkitab, yaitu dengan kajian eksegesis Alkitab untuk menemukan makna teks yang sesuai dengan konsep yang ada dalam surat Efesus 2: 8. Penulis mengadakan penelitian literatur (library research), terhadap berbagai sumber atau naskah-naskah yang memiliki korelasi dengan judul, antara lain: buku tafsiran-tafsiran kitab Efesus dan buku-buku yang berhubungan dengan kata kasih karunia yang disusun secara eksposisi untuk mencapai maksud, sasaran dan tujuan penulisan.

Berdasarkan hasil uraian penulis dalam karya ilmiah tentang makna kata kharis berdasarkan Efesus 2:8 dan implementasinya dalam kehidupan orang percaya masa kini, maka penulis dapat menarik kesimpulan sebagai berikut: Pertama, kasih karunia adalah kehadiran Allah melalui Yesus Kristus ke dalam dunia, mati untuk menyelamatkan manusia, Ia bangkit dari kematian untuk memberi kemenangan bagi orang percaya dan Ia menyediakan tempat di sorga bagi orang yang percaya kepadaNya. Kedua, kasih karunia merupakan anugerah keselamatan yang dianugerahkan oleh Allah secara cuma-cuma kepada manusia berdosa yang seharusnya dihukum dan dimurkai oleh Allah. Ketiga, kasih karunia merupakan kemerdekaan yang Allah berikan bagi manusia atas dosa, melepaskan dari kuasa iblis, memulihkan manusia untuk kembali bersekutu dengan Allah. Keempat, kasih karunia Allah merupakan pengampunan-Nya bagi orang berdosa yang datang bertobat kepada-Nya dengan sungguh-sungguh. Kelima, kasih karunia adalah kuasa Allah melalui kehadiran Roh Kudus yang memberdayakan setiap orang percaya untuk melawan godaan dosa, melakukan kehendak Allah, hidup dalam kekudusan dan memberi kemampuan melayani Tuhan serta menghadapi setiap masalah.
\end{abstract}

Kata kunci: Kharis, Efesus 2:8, dan Kehidupan Orang Percaya Masa Kini 


\section{PENDAHULUAN}

\section{Latar Belakang Masalah}

Semenjak kejatuhan manusia ke dalam dosa, manusia telah kehilangan kemuliaan Allah. Manusia menjadi musuh Allah karena ketidaktaatan dan pemberontakannya terhadap Allah. Hubungan manusia dengan Allah yang baik menjadi rusak sehingga ada jurang pemisah antara Allah dan manusia.Oleh karena itu, manusia harus dihukum mati karena upah dosa ialah maut (Roma 6:23), sedangkan manusia tidak memiliki kuasa untuk memperdamaikan dirinya dengan Allah. Namun, Allah mempunyai inisiatif untuk mendamaikan manusia kembali dengan diri-Nya, yaitu Allah mengutus Anak-Nya Yesus Kristus ke dalam dunia dan melalui kematian-Nya di kayu salib untuk menebus manusia dari dosa sehingga manusia yang seharusnya dihukum mati dapat dibebaskan oleh Allah.Inilah yang dinamakan dengan kasih karunia.

Pernyataan ini menunjukkan bahwa kasih karunia merupakan pengampunan Allah terhadap dosa-dosa manusia, penerimaan-Nya terhadap manusia yang sudah tercemar oleh dosa dan pertolongan-Nya bagi manusia yang tidak berdaya karena akibat dosa. Allah menyelamatkan manusia atas dasar kasih-Nya, bukan atas dasar perbuatan atau keberadaan manusia. Manusia sama sekali tidak layak menerima keselamatan, tetapi kasih Allah begitu besar bagi manusia yang berdosa. Bukan hanya sebatas menganugerahkan keselamatan, namun Ia juga terus berperan aktif menjadi Penolong bagi manusia.

Kehidupan jemaat di Efesus sebelum percaya kepada Yesus, mereka hidup dalam dosa dan pelanggaran, yaitu terlibat dalam penyembahan berhala, dikuasai oleh kuasa kegelapan, diperbudak oleh dosa. Keberadaan mereka sebagai orang berdosa, mengalami kematian dan dimurkai oleh Allah atas pemberontakan mereka. Tetapi oleh kemurahan Allah maka mereka beroleh penebusan yaitu pengampunan dosa dan diselamatkan oleh Allah tanpa syarat. Walaupun mereka adalah manusia berdosa tetapi oleh kasih karunia, Allah menyelamatkan mereka, itu bukan karena usaha, perbuatan baik, tetapi oleh iman di dalam Yesus Kristus.

Dalam Perjanjian Baru, "Kasih karunia adalah kehadirandan kasih Allah melalui Kristus Yesus yang diberikan kepada orang percaya oleh Roh Kudus, sambil memberikan kemurahan, pengampunan, dan keinginan serta kuasa untuk melakukan kehendak Allah (Yoh. 3:16; 1 Kor 15:10; Flp 2:13; 1 Tim 1:15-16)." Kasih karunia adalah pengampunan Allah

\footnotetext{
${ }^{1}$ Alkitab Terjemahan Indonesia
} 
kepada manusia yang berdosa. Kasih karunia adalah kuasa Allah yang senantiasa menyertai orang percaya melalui kehadiran Roh Kudus, dalam melayani, menjalankan kehendak Allah, kemurahan-Nya yang memberi kesempatan kepada orang berdosa datang bertobat, percaya dan diselamatkan. Allah memberikan kasih karunia kepada orang yang belum percaya sehingga mereka dapat percaya (Titus 2:11), dapat berdoa, melakukan kehendak-Nya, melayani Dia, menghampiri-Nya karena kemurahan dan kuasa-Nya. Kasih karunia memerdekakan manusia dari dosa ( $\mathrm{Rm}$ 6:20,22), semua kegiatan hidup manusia berjalan hanya karena kemurahan Allah.

Masalahnya manusia tidak begitu mengerti, menerima sepenuhnya apa sebenarnya makna dan tujuan dari kasih karunia Allah. Manusia mencoba membangun jembatan untuk menyeberangi jurang pemisah antara dia dan Allah yaitu dengan cara menambah keselamatan dengan jasa perbuatan baik untuk membalas kasih karunia Allah.

Teologi Roma Katolik menganut kepercayaan bahwa dengan melakukan perbuatan baik dan berusaha, maka mereka dapat memperoleh keselamatan. Hal ini menunjukkan bahwa masih ada orang-orang yangbelum mengerti dan percayabahwa hanya kasih karunia Allah yang dapat menyelamatkan manusia tanpa perbuatan baik dari manusia. Mereka seolah-olah mampu membayar keselamatan dari Allah dengan cara mereka sendiri. Didukung lagi dengan prinsip kehidupan zaman sekarang yang mana hampir segala sesuatu serba dibeli atau tanpa gratis.

Anton Bakker menyatakan dalam bukunya bahwa:

Gereja mempercayai adanya api penyucian, bukan suatu tempat tersendiri yang lain daripada surga maupun neraka. Api penyucian diterima sebagai keadaan orang meninggal yang belum layak menikmati kepenuhan kemuliaan Tuhan, karena rahmat Tuhan belum sampai meresapi dan mengubah seluruh dirinya. Api penyucian merupakan suatu proses pembersihan manusia sampai sedalamdalamnya sebelum ia sanggup mendekati Allah Yang Maha Kudus atau dapat masuk surga. Penderitaan ini adalah penderitaan sementara, untuk melunasi hukuman dosa yang masih tertingal. Mereka sendiri tidak bisa berbuat jasa untuk memperpendek penderitaan itu. Oleh sebab itu Gereja mendoakan mereka kepada kemurahan Allah kita. ${ }^{2}$

\footnotetext{
${ }^{2}$ Anton Bakker, Ajaran Iman Katolik 2 (Yogyakarta: Kanisius, 1988), 140.
} 
Gereja katolik percaya ada api penyucian bagi mereka yang belum layak menikmati kemuliaan Tuhan. Mereka yang meninggal tidak sanggup mendekati Tuhan karena mereka tidak layak. Mereka akan mengalami penderitaan sementara untuk melunasi hutang dosa mereka. Hal ini menyatakan dengan jelas bahwa mereka dapat memperoleh keselamatan melalui api penyucian, tetapi Firman Tuhan mengatakan bahwa keselamatan adalah anugerah Tuhan kepada manusia yang berdosa oleh iman di dalam Yesus Kristus.

Kata kharis, sering dijumpai dalam surat-surat Rasul Paulus, dia selalu memakai kata kharis ini sebagai salam pada saat memulai tulisannya, dalam pengajarannya, bahkan juga saat mengakhirinya. Seperti yang dijelaskan oleh ayat-ayat di bawah ini. Dalam Roma 3:24,"dan oleh kasih karunia(kharis) telah dibenarkan dengan cumacuma karena penebusan dalam Kristus Yesus."Dalam Roma 16:23,"Kasih karunia (kharis) Tuhan Yesus menyertai kamu."Di dalam Perjanjian Baru kata, kharis ditulis 155 kali." ${ }^{3}$

Rasul Paulus banyak memakai kata kharis dalam setiap surat yang dia tulis dan kata kharis memiliki makna yang luar biasa sehingga penulis melihat kata kharissebagai suatu hal yang menarik untuk diteliti dan menggali kebenaran yang terkandung di balik kata kharis. Penulis ingin mengetahui apa makna di balik kata kharis.Hal inilah yang melatarbelakangi penulis untuk menulis karya ilmiah yang berjudul: "Makna Kata Kharis Berdasarkan Surat Efesus 2:8 Dan Implementasinya Dalam Kehidupan Orang Percaya Masa Kini."

\section{Masalah Pokok}

Dengan melihat latar belakang di atas, maka yang menjadi pokok permasalahan dalam penulisan penelitian ini adalah:

Pertama, apa sebenarnya makna di balik kata kharis menurut Efesus 2:8? Kedua, bagaimana kharis diimplementasikan dalam kehidupan orangorang percaya masa kini?

\section{Tujuan Penulisan}

Sesuai dengan permasalahan yang diamati, maka tujuan dari penulisan penelitian ini adalah: Pertama, untuk menganalisis dan menafsirkan makna di balik kata kharis berdasarkan Efesus 2: 8. Kedua, untuk membahas bagaimana mengimplementasikan kharis dalam kehidupan orang-orang percaya masa kini.

${ }^{3}$ Hasan Susanto, Perjanjian Baru InterlinearYunani-Indonesia (Jakarta: LAI, 2002), 


\section{Manfaat Penulisan}

Adapun manfaat dari penulisan penelitian ini adalah sebagai berikut: Pertama, bermanfaat untuk menambah wawasan dan pemahaman pembaca tentang arti kata kharis. Kedua, untuk mengembangkan ilmu dan menambah wawasan bagi penulis secara pribadi bagaimana mengeksegesis dan menafsirkan makna sebuah kata dalam Alkitab.

\section{Metode Penelitian}

Dalam penulisan penelitian ini, penulis menggunakan metode penelitian naskah Alkitab. Penulis mengadakan penelitian literatur (library research), terhadap berbagai sumber atau naskah-naskah yang memiliki korelasi dengan judul, antara lain: buku tafsiran-tafsiran kitab Efesus dan buku-buku yang berhubungan dengan kata kasih karunia yang disusun secara eksposisi untuk mencapai maksud, sasaran dan tujuan penulisan.

\section{Batasan Penulisan}

Mengingat luasnya kata kasih karunia yang ditulis dalam Alkitab Perjanjian Baru, penulisan penelitian ini hanya akan khusus membahas konsep kasih karunia di dalam surat Efesus 2: 8. Pengambilan ayat-ayat Firman Tuhan dalam Perjanjian Baru yang ada kaitannya dengan penulisan penelitian ini sebagai ayat referensi atau mendukung penggunaan kata kharis yang lebih luas dalam dalam Perjanjian Baru. 


\section{EKSEGESIS EFESUS 2: 8 TENTANG KASIH KARUNIA}

\section{Latar Belakang Efesus 2: 1-10}

Keberadaan Efesus 2:1-10 adalah rangkaian kata-kata dari penulis surat yaitu Paulus. Efesus 1:3-6 yang mengandung ucapan syukur atas kasih karunia Allah yang dirasakan Paulus secara pribadi. Dalam ayat selanjutnya Paulus bermaksud membimbing anggota jemaat agar lebih mendalami pengetahuan mengenai anugerah Allah (1:17; 3:17-19). Alasan Paulus menulis bagian ini karena latar belakang kehidupan orang-orang Efesus sebelum percaya kepada Kristus, mereka sangat dipengaruhi oleh adat kepercayaan dan kebudayaan yang begitu melekat dalam diri mereka sehingga hal ini yang dipegang erat sebagai pegangan hidup. Sebagaimana telah dijelaskan sebelumnya bahwa Efesus adalah pusat pemujaan berhala yang sangat terkenal di kuil dewi Artemis yang disembah oleh seluruh Asia dan sangat terkenal sampai ke seluruh penjuru dunia (Kis 19:27).

Jadi, kepercayaan orang-orang di Efesus telah menyatu dengan kehidupan mereka, sehingga nama dewi Artemis juga terkenal di manamana. Wesley Brill mengatakan:

Di dalam candi itu ada imam-imam dan imam perempuan yang tak lain dari perempuan sundal. Kelakuan yang dilakukandalam penyembahan adalah buruk sekali. Imam-imam biasa menjual jimatjimat yang diakui paling mujarab di dunia. Perangai dan tabiat orangorang Efesus seperti persembahan dalam candi yakni bertahyul, penuh percabulan, melanggar hukum. Efesus disebut "ibu ilmu sihir" dan pusatnya ilmu sihir. ${ }^{4}$

Keadaan inilah yang Paulus temukan sendiri saat ia melakukan pelayanan di Efesus (Kis 19). Jadi, jika keadaan ini dihubungkan dengan Efesus 2:1-10, maka dapat disimpulkan bahwa Paulus ingin menjelaskan kepada orang-orang percaya yang ada di Efesus betapa besar dan ajaibnya kasih karunia Allah bagi mereka,walaupun mereka dahulu memiliki kehidupan yang jauh dari Allah, hidup di luar Kristus dan yang bertahan dengan cara-cara hidup yang tidak berkenan kepada Allah, namun itu semua tidak dapat mempengaruhi Allah untuk mengasihi mereka.

Pembahasan mengenai kasih karunia di dalam Efesus 2:1-10 ini juga disebabkan adanya ajaran sesat yang dibawa oleh guru-guru palsu ke dalam jemaat yang ada di Efesus (6:10). Dan terbukti dengan adanya cacatan dalam Kis 19:29-30 mengenai keyakinan Paulus terhadap adanya

\footnotetext{
${ }^{4}$ J. Wesley Brill, Surat-surat Kepada Ketujuh Jemaat (Bandung: Kalam Hidup,1970), 18.
} 
pengajar-pengajar sesat yang digambarkan sebagai serigala-serigala yang akan masuk ke dalam jemaat Efesus setelah Paulus meninggalkan mereka.

Dengan demikian Paulus menulis surat kepada Timotius (1 Tim 1:3; 2 Tim 2:17-18) agar Timotius tetap tinggal di Efesus dan menasihati orang-orang tertentu agar tidak mengajarkan ajaran sesat yang bertentangan dengan kebenaran Injil. Mereka itu ialah Himeneus dan Filetus.

Pengikut Nikolaus dengan ajarannya ternyata telah menyusup masuk dan berkembang dalam jemaat Efesus dan jemaat lainnya (Why. 2:6; 2:15). Jadi, dengan adanya ajaran sesat yang masuk di jemaat Efesus maka, J.I. Packer, Merrill C. Tenney dan William White menjelaskan dalam buku mereka bahwa:

Yohanes memusatkan perhatiannya pada bentuk gnostik yang lebih ekstrim yang merajalela selama gereja abad pertama (1 dan 2 Yohanes, Wahyu 2:6, 14, 15). Kelompok itu adalah pengikut Nikolaus (Nicolatians). Para pendukung doktrin yang mematikan ini mengatakan bahwa karena tubuh mereka adalah fisik (dan karenanya jahat), maka hanya perbuatan-perbuatan roh merekalah yang penting. Jadi mereka merasa bebas untuk melakukan hubungan seksual semaunya, memakan makanan yang telah dipersembahkan kepada para dewa, dan melakukan apa saja yang mereka inginkan dengan tubuh mereka.

Sebagian orang di Efesus salah menilai tentang tubuh mereka, mereka mengutamakan perbuatan dalam roh tetapi mengabaikan perbuatan yang dilakukan dengan tubuh, jadi setiap perbuatan yang bersifat kedagingan, mereka menganggapnya biasa saja. Maka dengan adanya ajaran sesat yang telah tersebar di jemaat Efesus, maka hal inilah yang menyebabkan Paulus ingin menjelaskan kepada jemaat Efesus bahwa kasih karunia Allah bagi manusia berdosa bukan untuk melakukan dosa tetapi untuk melakukan pekerjaan baik dan yang berkenan kepada Allah (Ef 2:10). Dengan demikian, dapat disimpulkan bahwa penulisan Efesus 2:1-10 disebabkan adanya beberapa hal yang melatatar belakanginya, yaitu:

Pertama, sebagai luapan hati Paulus secara pribadi yang bersyukur kepada Allah karena ia telah merasakan betapa besar kasih karunia Allah yang ia telah rasakan dalam hidupnya.

Kedua, Paulus ingin menjelaskan kepada jemaat Efesus bahwa kasih karunia Allah yang telah dianugerahkan kepada mereka bukanlah karena usaha dan jerih lelah yang mereka lakukan, bukan karena adat

${ }^{5}$ J.I. Packer, Merrill C. Tenney dan William White, Dunia Perjanjian Baru (Surabaya: Yakin dan Gunung Mas, 1995), 213. 
kepercayaan, budaya yang mereka miliki serta banggakan dan budaya yang dijunjung tinggi oleh mereka. Dahulu mereka hidup dalam dosa dan pelanggaran yaitu mereka terlibat dalam penyembahan berhala, hidup dalam hawa nafsu kedagingan, hidup di bawah kuasa kegelapan, mengikuti jalan dunia yang jahat ini, namun mereka diselamatkan hanya karenakasih karunia Allah semata-mata, bukankarena perbuatan, hasil usaha dan pekerjaan mereka.

Pemahaman terhadap kasih karunia akan menjadi tidak jelas atau samar-samar untuk dimengerti apabilahanya langsung pada 2:8, maka penulis perlu untuk membahas dari 2:1-10, supaya dapat memahami apa maksud dari 2:8 yaitu tentang kasih karunia. Jadi ada beberapa bagian dari 2:1-10, yaitu sbb:

\section{Keadaan Hidup Orang di Luar Kristus 2:1-3}

Dalam 2:1-3 Paulus menjelaskan kehidupan orang yang berada di luar Kristus, Paulus menunjukkan apa saja yang dialami oleh orangorang yang hidup di luar Kristus. Keadaan orang yang hidup di luar Kristus adalah:

\section{Mengalami Kematian}

Dalam ayat 1, "Kamu dahulu sudah mati karena pelanggaranpelanggaran dan dosa-dosamu" dan dalam bahasa Yunaninya kaiumas ontas nekrous tois paraptomasin kai tais amartiais umon. ${ }^{6}$ Hidup di luar Kristus adalah hidup di dalam dosa dan pelanggaran.

Kematian manusia secara rohanidiakibatkan oleh dosa dan pelanggaran, maka manusia tidak memiliki kuasa untuk kembali hidup secara rohani. Akibat dosa sangat fatal sehingga membuat manusia tidak berdaya lagi untuk melakukan hal yang benar di hadapan Tuhan. Berarti "Kematian adalah hukuman yang dijatuhkan Allah. Roma 6:23 menyatakan bahwa maut adalah upah dosa, artinya ganjaran yang patut atas dosa." ${ }^{7}$ Kematian memang suatu hal yang fatal sebagai upah yang pantas diterima oleh manusia karena akibat dosa. "Kata 'mati' disini harus dimengerti dalam terang Ef 4:18, yaitu jauh dari hidup persekutuan dengan Allah lalu berada di bawah hukuman-Nya yang adil atas dosa. Akibat dosa yang paling dasyat ialah, Allah dan manusia terpisah (Yesaya 59:2)." Akibat dosa dapat memisahkan manusia dari Allah, jauh dari persekutuan dengan Allah dan akan terus membuat manusia semakin jauh dan tinggal dalam kegelapan sehingga manusia tidak mengerti kehendak Tuhan karena tidak lagi diterangi oleh kebenaran

\footnotetext{
${ }^{6}$ E-sword-the Lord With An Electronic.

${ }^{7}$ Ensiklopedi Alkitab Masa Kini, Jilid II (Jakarta: Yayasan Komunikasi Bina Kasih, 1995), 30.

${ }^{8}$ Tafsiran Alkitab Masa Kini, Jilid 3 (Jakarta: BPK Gunung Mulia, 1983), 606.
} 
Allah. Inilah tindakan Allah yang adil atas dosa. "Kematian rohani merupakan terpisahnya jiwa dari Allah. Hukuman yang dinyatakan di Taman Eden dan telah menimpah umat manusia, terutama berarti kematian rohani (Kej. 2:17; Roma 5:21; Ef 2:1,5). Dengan kematian rohani manusia tidak lagi menikmati kehadiran dan kebaikan Allah dan bahkan tidak lagi mengenal dan merindukan Allah."

Jadi, kata "mati" yang tertulis dalam 2:1 menunjukkan kepada kematian rohani. Melalui beberapa penjelasan di atas dapat disimpulkan pengertian kematian rohani, yaitu (1) Kematian manusia secara rohani dan terpisahnya jiwa dari Allah adalah sesuatu yang sangat buruk karena terpisah dari Allah, sedangkanAllah adalah sumber kehidupan. (2) Kematian manusia secara rohani mengakibatkan ketidakberdayaan manusia untuk kembali kepada Allah, tidak berguna lagi di hadapan Allah, tidak dapat berbuat apa-apa karena terlepas dari Pemberi hidup. Dengan demikian, jelaslah bahwa manusia tidak dapat kembali ke dalam kondisi semula, manusia sama sekali tidak memiliki kekuatan untuk memperbaiki hubungannya dengan Allah, bahkan tidak dapat melakukan sesuatu yang baik di mata Tuhan. (3) Kematian idak ada lagihubungan yang baik dengan Allah. Hubungan yang harmonis menjadi rusak, tidak mengenal Allah dengan benar dan kerinduan terhadap Allah sudah lenyap. Hidup di luar keselamatan, tidak menikmati berkat-berkat Allah.

Membahas tentang kematian rohani yang dialami oleh manusia, maka perlu juga membahas penyebab dari kematian manusia secara rohani. Ada beberapa alasan mengapa manusia harus berada di dalam kondisi mati secara rohani adalah:

Pertama, karena pelanggaran. Dalam Efesus 2:1, mencatat salah satu penyebab manusia mengalami kematian dan terpisah dari Allah, yaitu paraptomasin, Noun Datif Neuter Plural, yang berasal dari kata paraptoma yang berarti trespass (kesalahan atau dosa), false step (langkah atau tindakan tidak benar), transgression (tindakan melanggar hukum, pelanggaran) ${ }^{10}$ dalam arti harafiahnya adalah tergelincir atau jatuh. "istilah ini digunakan untuk menggambarkan seseorang yang kehilangan arah jalan atau tersesat; juga dapat berarti gagal atau meleset dalam menangkap kebenaran." " Ada dua aspek yang ditemukan dalam penjelasan di atas bahwa ada aspek kesengajaan dan ketidaksengajaan. Sengaja atau tidak sengaja semuanya adalah pelanggaran. Jadi,

\footnotetext{
${ }^{9}$ Henry C. Thissen, Theologi Sistematika, (Malang: Gandum Mas, 1993), 299.

${ }^{10}$ BMG Morphology Analysis, s.v. paraptomasin In Bible Works.Version 7.

${ }^{11}$ William Barclay, Pemahaman Alkitab Setiap HariGalatia-Efesus(Jakarta: BPK Gunung Mulia, 1983), 143.
} 
pelanggaran merupakan mengikuti jalan yang tidak benar, bertindak ke arah yang tidak benar atau berlaku tidak setia.

Kedua, karena dosa. Mengenai kata "dosa", dosa penyebab

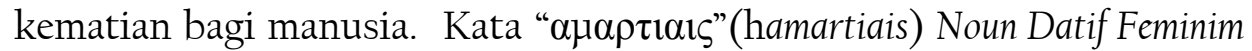
Plural yang berasal dari kata hamartia, yang berarti sin, sinful deed, ${ }^{12}$ yaitu suatu istilah mengenai perburuan. "Secara harafiah kata itu berarti meleset. Dosa adalah kegagalan untuk mencapai sasaran hidup. Itulah sebabnya mengapa dosa itu bersifat universal." ${ }^{13}$ Berarti dosa adalah kegagalan manusia dalam mencapai sasaran-sasaran yang sesuai dengan ketentuan-ketentuan yang telah ditetapkan oleh Allah dalam kebenaranNya. Tetapi terkadang manusia salah memahami dan menilai tentang dosa itu, manusia mengira kalau dosa itu hanya menyangkut kesalahankesalahan besar seperti membunuh, mencuri, merampok. Manusia sendiri yang membuat ukuran atau standar bagi dosa dan mengelompokkannya sesuai dengan keinginannya sendiri. Namun, yang dimaksudkan oleh Paulus dalam ayat ini bahwa dosa adalah tindakan yang meleset atau kegagalan mencapai sasaran. Inilah kegagalan manusia dalam memenuhi standar Allah. Dalam Efesus, dosa merupakan tindakan dalam penyembahan berhala, hidup dalam kedagingan, menuruti hawa nafsu, menuruti penguasa dunia atau roh-roh jahat, dan segala macam kecemaran.

Dengan demikian pelanggaran dan dosa merupakan penyebab kamatian bagi manusia di luar Kristus. Keterpisahan manusia dengan Allah adalah suatu realita yang menunjukkan ketidakbardayaan manusia, ketidakmampuannya untuk kembali kepada Allah. Tetapi Allah sendiri berinisiatif untuk menyelamatkan manusia dengan kasih karunia-Nya, sehingga manusia kembali memiliki persekutuan yang harmonis dengan Allah.

Ketiga, mengikuti jalan dunia. Dalam ayat 2 "Kamu hidup di dalamnya, karena kamu mengikuti jalan dunia ini, karena kamu mentaati penguasa kerajaan angkasa, yaitu roh yang sekarang sedang bekerja di antara orang-orang durhaka." Dalam bahasa Yunaninya en ais pote periepatesate kata ton aiona tos kosmou toutou, kata ton arxonta tos exousias tos aeros, tos pneumatos tos nsn energosntos en tois uiois tos apeitheias. ${ }^{14}$ Kata periepatesate bentuk Verb Indikatif Aourist, Plural, Aktif dari kata "peripateo" yang berarti, to walk about (berjalan keliling, dengan), to conduct ones life

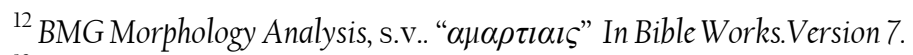

${ }^{13}$ William Barclay, Pemahaman Alkitab Setiap Hari Galatia-Efesus (Jakarta: BPK

${ }^{14}$ E-sword-the Lord With An Electronic.
} Gunung Mulia, 1983), 141. 
(bertingkah laku, mengatur, membimbing, memimpin suatu kehidupan)." ${ }^{15}$

Kata "mengikuti" dari kata "peripatein" yang berarti berjalan keliling, dan dalam bahasa indonesia diterjemahkan dengan: hidup, melakukan, berjalan, berada di dalam, terus-menerus melakukan."16 Jadi, mereka yang mengikuti jalan dunia ini berada di dalam atau berjalan dalam dunia yang penuh dengan dosa dan terus-menerus melakukan dosa. Kata "dunia" dari kata "kosmos" dan kata ini Paulus sering pakai. "Kosmos" di sini ialah dunia sebagai keseluruhan periode dunia, dunia yang gerak, hampir sebagai waktu yang sedang berlangsung., ${ }^{, 17}$ Maksud Paulus bahwa jemaat di Efesus mengikuti waktu yang terus berjalan dalam dunia, waktu itu yang menguasai mereka sehingga mereka benarbenar "hidup di bawah pengaruh jahat." ${ }^{18}$ Penjelasan ini sesuai dengan latar belakang hidup orang-orang Efesus yang dahulunya menyembah kepada dewi Artemis. Akibat dari penyembahan berhala mempengaruhi seluruh keberadaan hidup mereka karena kuasa yang bukan dari Tuhan yang menguasai mereka dan terus-menerus hidup di dalam dosa atau tanpa mengenal kebenaran. Hal inilah yang pernah terjadi di Efesus sehingga membuat mereka tidak berdaya mengikuti jalan kebenaran tetapi mengikuti jalan dunia. J.L. Ch. Abineno mengatakan:

Untuk dapat memahami maksud kalimat ini kita harus memperhatikan tanggapan orang (gambaran dunia) pada waktu itu. Menurut tanggapan itu, dunia terdiri dari beberapa lapisan (bnd 2 Kor 12:2). Lapisan udara atau angkasa didiami oleh roh-roh. Roh jahat yang mempunyai pengaruh buruk atas manusia. Dalam nas kita dikatakan bahwa ada suatu "archon" yang mempunyai "exousia" yaitu "aer". Yang dimaksudkan di sini dengan "archon" ialah penguasa dan pemerintah. Archon ini yang dikatakan di atas, mempunyai exousia. Exousia di sini bukanlah kuasa (wewenang), pemerintahan, tetapi juga seperti Kol 1:13, daerah pemerintahan (kerajaan). Daerah pemerintahan ini ialah "aer": udara, angkasa, (yang biasa dilukiskan sebagai tempat yang gelap, bnd Efesus 6:12; Kol 1:13).

${ }^{15}$ Fritz Rienecker, A Linguistic Key To The Greek New Testament, Vol. 2, Romans Revelation (Grand Rapids Michigan: Zondervan Publishing House, 1980), 178.

${ }_{17}^{16}$ J. L. CH. Abineno, Tafsiran Surat Efesus (Jakarta: BPK,1971), 43.

${ }^{17}$ Ibid.

${ }^{18}$ Jalan dunia ini, 'har' menurut zaman (Yun. aion) tata dunia ini (Yun. kosmos), melihat hidup manusia di bawah pengaruh jahat dari pada kuasa di langit yang dengan lalim menggemgam manusia (Tafsiran Alkitab Masa Kini Jilid 3, hal. 606).

${ }^{19}$ J.L. Ch. Abineno, Tafsiran Surat Efesus (Bandung: BPK, 1971), 44. 
Yang dimaksud dengan penguasa kerajaan angkasa di sini yaitu roh yang sedang bekerja di antara orang-orang durhaka. Penguasa kerajaan angkasa ialah iblis dengan pengikutnya yang mempunyai kuasa yang besar dan dapat mempengaruhi manusia serta mengikat manusia sehingga manusia menjadi pengikutnya (Efesus 6:12).

Keempat, mentaati penguasa kerajaan angkasa. Inilah bentuk pelanggaran yang dilakukan oleh manusia yang hidup di luar Kristus yaitu mereka mentaati penguasa kerajaan angkasa. Sebenarnya tidak jauh berbeda dengan mengikuti jalan dunia dan mentaati penguasa kerajaan angkasa. Apabila ditinjau dari kata "mengikuti" dan "mentaati", karena "mengikuti" merupakan unsur dari sebuah "ketaatan" sedangkan "ketaatan" adalah titik tolak untuk "mengikuti" sesuatu. Jadi, mengikuti sesuatu merupakan bukti ketaatan. Kedua kata ini sangat erat hubungannya terbukti di Efesus 2:2 "kata ton arxonta tos exousias tos aeros", maka dapat disimpulkan bahwa sebelum orang-orang di Efesus percaya kepada Allah, mereka hidup dalam ketaatan kepada penguasa kerajaan angkasa, yaitu mereka ada di tangan penguasa dan dikuasai olehnya.

Kata arkhonta dalam bentuk Noun Akusatif Maskulin Singular, yang berasal dari kata "arkhon" yang berarti ruller, lord, prince (pangeran, raja, penguasa), ${ }^{20}$ atau "penguasa, petugas, pemimpin. Anggota sanhedrin, hakim/orang Yahudi, pejabat/orang Yunani, penguasa/supernatural." ${ }^{21}$ Penguasa menunjukkan kepada oknum yang berperan penting, memiliki pengaruh besar atau orang yang memiliki tugas yang penting. Jadi, mereka yang ada di Efesus taat kepada penguasa kerajaan angkasa, hal ini terjadi karena Efesus merupakan pusat penyembahan berhala dan dengan demikian mereka yang ikut dalam penyembahan berhala dikuasai oleh kuasa berhala serta mentaati kuasa ini dengan memberontak kepada Allah.

Kesimpulan dari ayat 2, yaitu bahwa mereka hidup, tinggal diam dalam dosa atau tetap melakukan perbuatan-perbuatan yang melanggar perintah Tuhan dan mereka terus-menerus ikut jalan dunia ini yaitu dunia yang penuh dengan kejahatan. Iblislah yang sedang (sesuatu yang terus berlangsung, terus menerus atau tanpa berhenti) bekerja di antara orang-orang durhaka. Iblis ada dalam dunia ini yaitu ia berada "Dalam kosmologis kuno kawasan antar bintang, terutama antara bulan dari bumi, dianggap sebagai pangkalan untuk kegiatan demonis yang tetap, dengan akibat buruk yang menimpa penghuni bumi." ${ }^{22}$

\footnotetext{
${ }^{20}$ BMG Morphology Analysis, s.v. arkhonta" In Bible Works.Version 7.

${ }^{21}$ Hasan Sutanto, Perjanjian Baru Yunani-Indonesia dan Konkordansi Perjanjian Baru (Jakarta: Lembaga Alkitab Indonesia, 2003), 121.

${ }^{22}$ Tafsiran Alkitab Masa Kini, Jilid 3 (Jakarta: BPK Gunung Mulia, 1976), 606.
} 
Jadi, manusia yang dikuasai oleh iblis berada di bawah kuasa iblis sehingga mereka tidak dapat hidup dalam Kristus dan orang-orang ini akan selalu bertingkah buruk sesuai dengan pekerjaan iblis yang menguasai mereka.

\section{Mengalami Kemurkaan}

Selain kematian, orang-orang yang hidup di luar Kristus juga akan dimurkai. Kata "dimurkai" opүns (orges) bentuk Noun Genetif Feminim Singular, berasal dari kata orge yang berarti wrath (kegusaran, kemarahan, kemurkaan), anger (marah, kemarahan, keberangan, kegusaran, amarah, murka), indignation (kemarahan, kejengkelan, kedongkolan). ${ }^{23}$ "Kemurkaan" adalah kata benda tunggal. Inilah hal yang Allah lakukan bagi orang yang hidup di luar Kristus. Dalam konteks ini bahwa Allah memurkai orang-orang yang hidup dalam pelanggaran dan dosa. Mereka ini dimurkai ${ }^{24}$ oleh Allah. Dimurkai berarti berada "Di bawah penghakiman Allah karena pemilihan moral, yang berasal dari tabiat manusia yang telah bengkok.". ${ }^{25}$ Dalam keadaan di luar Kristus, manusia selalu memberontak dan menentang Allah, maka akan dimurkai oleh Allah yaitu dihukum oleh Allah sendiri.

Jadi, dalam ayat 1-3 menggambarkan keadaan orang yang hidup di luar Kristus, hidup dalam dosa, pemberontakkan terhadap Allah dan hidup di bawah kuasa iblis, maka harus mati atau dimurkai oleh Allah. Mereka dimurkai karena:

Pertama, hidup menuruti nafsu daging. Dalam ayat 3, kata

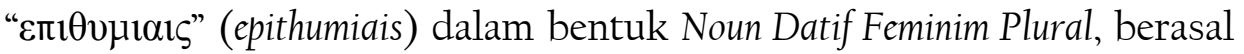
dari kata "epithumia" yang berarti eager (ingin sekali, hasrat), desire (hasrat, keinginan, berahi, berahi terhadap), longing (keinginan) ${ }^{26}$, "keinginan-keinginan yang buruk/jahat, hawa nafsu. Kata "боркоৎ" (sarkos), dalam bentuk Noun Genitif Feminim Singular, dari kata "sarks" yang berarti tubuh, daging, daging yang berdosa. ${ }^{27}$

Sarks: daging, daging yang berdosa, yang menjadi kuasa dan yang memerintah manusia. Sarks juga dapat berarti seluruh manusia sebagai

\footnotetext{
${ }^{23}$ BMG Morphology Analysis, s.v. "opyns" In Bible Works.Version 7.

${ }^{24}$ Sikap Allah yang kudus dan benar bila berkonfrontasi dengan dosa dan kejahatan di sebut 'murka-Nya'. Ketidakadilan dan kefasikan manusia, terhadap perbuatan mana manusia tidak dapat berdalih, harus diikuti pernyataan murka Allah yang menimpah hidup manusia, baik hidup perseorangan maupun bangsa-bangsa (Rom. 1:18-32), seperti penghancuran Sodom dan Gomora dalam PL (Ul. 29: 23). (Ensiklopedi Alkitab Masa Kini, s.v. 'Murka').

${ }^{25}$ Tafsiran Alkitab Masa Kini, Jilid 3 (Jakarta: BPK Gunung Mulia, 1976), 606.

${ }^{26}$ BMG Morphology Analysis, s.v. "Eпı $\theta v \mu ı$ aıs" In Bible Works.Version 7.

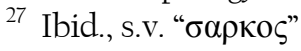


anak murka. Sarks juga menimbulkan keinginan-keinginan jahat (hawa nafsu). ${ }^{28}$ Jadi, hawa nafsu daging yang menguasai mereka sehingga membuat mereka egois yaitu dengan mengikuti keinginannya sendiri yang menyimpang dari kebenaran Allah. J. L. CH. Abineno mencatat dalam bukunya:

Hawa nafsu daging ini, menurut Paulus, memimpin orang kepada "kehendak daging" (thelemata tes sarkos) dan kehendak daging dan perbuatan. Keduanya kehendak daging dan perbuatan adalah pekerjaan "sarks". Kita dapat berkata: demikianlah kiranya "sarks" bekerja. Dalam kehendak "sarks" tidak ada kesatuan, tidak ada arah; kehendak itu tidak mengikut sesuatu norma, tidak dikuasai oleh suatu pikiran atau perasaan yang tidak berubah-ubah, tetapi berada di bawah pengaruh affek dan dorongan nafsu. Itulah sebabnya di sini dipakai bentuk jamak "ta thelemata". ${ }^{29}$

Dari penjelasan di atas dapat disimpulkan bahwa hidup dalam hawa nafsu daging adalah: (1) Mereka terus-menerus tinggal dalam keinginan daging, melakukan, dan berbuat apa yang bersifat kedagingan yang tidak sesuai dengan kebenaran Allah.(2) Mereka hidup di dalam daging dan daging mereka penuh dengan keinginan atau mereka berahi terhadap hal-hal yang jahat. (3) Kehidupan daging yang penuh dengan hawa nafsu atau berahi yang tidak dipimpin oleh satu aturan (norma) dan tidak terkendali karena keinginan itulah yang menguasai, memimpin dan memerintahnya untuk berbuat yang tidak benar.

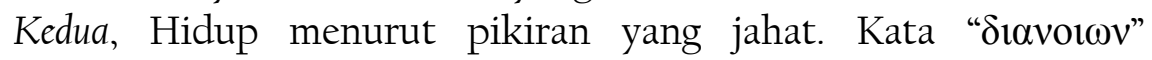
(dianoion), dalam bentuk Noun Gen. Fem. Plural, dari kata "dianoia" yang berarti mind (pikiran, akal, ingatan), intelligence (kecerdasan) ${ }^{30}$ dalam arti daya pikir, jalan pikiran, apa yang dipikir, dorongan hati. Kata "dianoia" adalah pikiran dan pertimbangan yang sadar dari sarks. Dengan menekankan sarks dan diakoia di alam manusia dalam totalitasnya dengan sadar menuruti kehendak dagingnya dan pelaksanaan dari kehendak itu" 31 Jadi, keinginan yang jahat itu benar-benar dari pikiran atau dorongan hati mereka. Pikiran yang jahat membuahkan tindakan yang jahat.

\section{Karya Allah Melalui Yesus Kristus 2:4-9}

Dalam ayat 4-9, Paulus menjelaskan karya Allah melalui Yesus Kristus bagi orang-orang berdosa yang seharusnya mati karena pelanggaran dan dosanya, tetapi diselamatkan oleh Allah melalui

${ }^{28}$ J. L. CH. Abineno, Tafsiran Surat Efesus (Jakarta: BPK,1971), 45.

${ }^{29}$ Ibid.

${ }^{30}$ BMG Morphology Analysis, s.v. "Siavoı $\omega v "$ In Bible Works.Version 7.

${ }^{31}$ J. L. CH. Abineno, Tafsiran Surat Efesus (Jakarta: BPK,1971), 46. 
kematian Yesus Kristus. Itulah karya Allah bagi manusia sebagai orangorang yang patut dihukum mati dan dimurkai oleh Allah. Tetapi Allah berkarya di dalam Yesus Kristus melalui:

\section{Kasih-Nya yang Besar}

Dalam 2:4 “...Oleh karena kasih-Nya yang besar, yang dilimpahkanNya kepada kita." Bahasa Yunaninya: ...dia ton pollon agapen autos en egapesen emas. $^{32}$

Kata agape $\hat{e}^{33}$, noun, akusatif, feminim, singular, yang berati love (cinta, kasih sayang), affection (kesayangan, kasih, kasih sayang)Karena Allah yang kaya dengan rahmat, Ia menunjukkan kasih sayang-Nya bagi manusia yang berdosa. Ia menjadikan manusia umat kesayangan-Nya, Ia menyelamatkan manusia karena cinta-Nya. Jadi karena kasih kasih sayang-Nya, cinta-Nya, maka Ia menyatakannya dengan :

Pertama, telah menghidupkan kita bersama-sama dengan Kristus. Dalam ayat 5, "telah menghidupkan kita bersama-sama dengan Kristus, sekalipun kita telah mati oleh kesalahan-kesalahan kita oleh kasih karunia kamu diselamatkan" dan dalam bahasa Yunaninya kai ontas emas nekrous tois paraptomasinsunezoopoiesen to xristo : xariti este sesosmenoi. ${ }^{34}$ Kata sunezoopoiesen bentuk aorist Aktif Indikatif, yang berasal dari kata suzoopoieo yang berarti to make alive together (membuat hidup bersama-sama dengan). The word is a synonim for the verb "to rise" (menghidupkan, menegakkan, mengangkat, menaikkan, mendirikan, menimbulkan) or "to preserve life" (memelihara, melindungi kehidupan). ${ }^{35}$

Jadi, sesuai dengan penjelasan yang ada maka dapat disimpulkan bahwa: (1) Kata "menghidupkan" muncul berarti ada kata "mati" sebelumnya, dalam arti bahwa manusia yang sudah mati karena pelanggaran dan dosanya, tetapi karena kasih-Nya yang besar Ia menghidupkan manusia, yaitu memberikan kepada manusia kehidupan yang baru yang sama sekali berbeda dari kehidupan sebelumnya waktu masih hidup di luar Kristus, Ia mengangkat manusia dari kematian; (2) Ia membawa manusia dekat dengan Dia karena keterpisahan manusia dari Dia karena dosa, sehingga manusia memiliki hubungan yang baik dengan Allah dan dapat berinteraksi dengan Allah dalam persekutuan; (3) Bahkan akan melindungi kehidupan manusia.Hal ini tidak dapat dilakukan dari pihak manusia karena ketidakberdayaannya manusia tetapi hanya dapat dilakukan oleh Allah saja melalui kasih karunia-Nya.

\footnotetext{
${ }^{32}$ E-sword-the Lord With An Electronic.

${ }^{33}$ STM Morphology Analysis, s.v. "agapê" In Bible Works.Version 7.

${ }^{34}$ E-sword-the Lord With An Electronic.

${ }^{35}$ BMG Morphology Analysis, s.v. "sunezoopoiesen" In Bible Works.Version 7.
} 
Sehubungan dengan tense yang ada dalam kalimat "menghidupkan kita bersama-sama dengan Kristus" ialah dalam bentuk aorist aktif indikatif, berarti perlindungan, pemeliharaan Allah kepada manusia telah dilakukan pada masa lampau dan akan terus-menerus berlaku atau berlangsung dari dulu, sekarang dan masa yang akan datang. Jadi, Paulus bermaksud menyampaikan hal ini kepada jemaat yang ada di Efesus bahwa kehidupan, perlindungan dan pemeliharaan Allah terhadap mereka adalah semata-mata kasih karunia Allah, bukan hasil dari jerih lelah atau usaha mereka. Hidup yang ada pada mereka merupakan kehidupan dalam Kristus yang telah hidup dari kematian, hidup yang Yesus berikan bagi mereka adalah hidup secara rohani.Mereka mengalami kehidupandari kamatian Yesus dan mereka bebas dari kematian rohani.

Kedua, membangkitkan kita bersama-sama Kristus. Dalam ayat 6, "dan di dalam Kristus Yesus Ia telah membangkitkan kita juga dan memberikan tempat bersama-sama dengan Dia di sorga" dan dalam bahasa Yunaninya, kai sunegeiren kai sunekathisen en tois "epouraniois en xristo iesos. ${ }^{36}$ Kata sunegeiren yang berasal dari kata "sunegeiro" yang berarti to raise up with any one (mengangkat ke atas dengan seseorang); to raise up with Cristby spiritual resemblance of His resurrection (mengangkat ke atas dengan Kristus melalui persamaan rohani dari kebangkitan-Nya). ${ }^{37}$ Kata "sunegeren" bentuk aorist aktif indikatif yang berasal dari kata "sunegeiro" yang berarti to raise together with (mengangkat bersama dengan). Believers not only receive life, but the experience a resurrection (orang-orang percaya tidak hanya menerima kehidupan tetapi mereka mengalami kebangkitan). ${ }^{38}$

Sesuai dengan penjelasan di atas, maka dapat disimpulkan mengenai manusia yang memperoleh kebangkitan, yaitu: (1) Allah mengangkat (membangkitkan) manusia bersama-sama dengan Kristus oleh kematian-Nya dan kebangkitan-Nya. Itu berarti manusia berpindah dari kematian menuju kepada hidup di dalam Allah."membangkitakan" berarti Allah bertindak mengangkat manusia dari hukuman atas dosa dan membawa manusia kepada persekutuan dengan Allah, dengan kata lain Allah yang Maha Kuasa menyatakan kuasa-Nya melalui kebangkitan Yesus Kristus dari kematian, sehingga manusia dapat menikmati persekutuan dengan Allah. (2) Kebangkitan yang dibahas dalam ayat 6, menunjukkan kebangkitan manusia dari kematian karena dosa,

\footnotetext{
${ }^{36}$ E-sword-the Lord With An Electronic.

${ }^{37}$ The Analytical Greek Lexicon, s.v. "sunegeiro"

${ }^{38}$ Fritz Rienecker, A Linguistic Key To The Greek New Testament, Vol. 2, RomansRevelation (Grand Rapids Michigan :Zondervan Publishing House, 1980), 179.
} 
kebangkitan rohani untuk bersatu dengan Kristus. Kebangkitan ini mengacu kepada kebangkitan tubuh kemuliaan (tubuh rohani).

Ketiga, Ia memberikan tempat bersama-sama dengan Dia. Kata sunekathisen, aorist Aktif Indikatif yang berasal dari kata "sunkathizo" yang berarti to cause to sit down together with another (sebabnya kita duduk bersama-sama dengan). ${ }^{39}$ Jadi hanya karena kasih karunia Allah yang memberikan tempat bagi kita di sorga. Kedudukan orang yang percaya di sorga diberikan oleh Allah dan bukan karena manusia yang mengusahakannya.

Keempat, Ia menunjukkan kekayaan kasih karunia-Nya. Dalam ayat 7, "supaya pada masa yang akan datang Ia menunjukkan kepada kita kekayaan kasih karunia-Nya yang melimpah-limpah sesuai dengan kebaikan-Nya terhadap kita dalam Kristus Yesus" dan dalam bahasa Yunaninya, ina endeixetai en tois aiosin tois eperxomenois to huper ballon plostos tos xaritos autos en xrestoteti ef' emas en xristo iesos ${ }^{40}$. Kata "endeixetai" berasal dari kata "endeiknumi" berarti: menunjukkan, mendemontrasikan, begitu rupa, sehingga nyata (nampak, kelihatan) kepada tiap-tap orang." ${ }^{41}$ Adapun yang akan Dia tunjukkan kepada manusia pada masa yang akan datang, yaitu Ia menunjukkan kekayaan yang melimpah-limpah dari kasih karunia-Nya.

Pada masa yang akan datang, Allah akan menunjukkan kepada manusia yang telah dihidupkan, dibangkitkan dan diberi tempat di sorga bersama-sama dengan Kristus, bahwa betapa kayanya kasih karunia Allah bagi mereka dari zaman ke zaman, dari waktu yang lampau Ia tetap menyatakan kasih-Nya dan pada waktu itu orang-orang percaya akan dapat memahami betapa Allah mengasihi mereka. Kata "kekayaan" mempertegaskan bahwa kasih-Nya melebihi ukuran atau tanpa batas. Kasih-Nya yang Ia tunjukkan kepada manusia bukan berdasarkan atau sesuai dengan kebaikan mereka tetapi sesuai dengan kebaikan-Nya dalam Yesus Kristus.

\section{Manusia Diselamatkan}

Manusia diselamatkan oleh kasih karunia-Nya melalui karya Allah

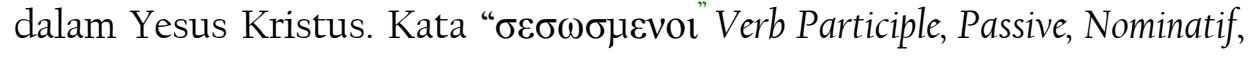
Maskulin,dari kata "sozo" yaitu untuk menyimpan, memberikan atau melindungi (secara harfiah atau kiasan): menyembuhkan, melestarikan, menyimpan (diri), melakukannya dengan baik). ${ }^{42}$ Dengan kasih karunia,

\footnotetext{
${ }^{39}$ Fritz Rienecker, A Linguistic Key To The Greek New Testament, Vol. 2, RomansRevelation (Grand Rapids Michigan :Zondervan Publishing House, 1980), 179.

${ }^{40}$ E-sword-the Lord With An Electronic.

${ }^{41}$ J.L. CH. Abineno, Tafsiran Surat Efesus (Jakarta: BPK, 1971), 49.

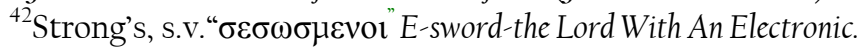


Allah menyelamatkan dan melindungi manusia dan Ia melakukannya dengan baik. "Membawa aman, sembuh, memastikan keselamatan, mendapatkan, dibuat dengan baik, memulihkan, menyimpan." ${ }^{43}$ Ia memulihkan manusia melalui kasih karunia-Nya.

"Sozo: rescue (menolong), liberate (membebaskan, memerdekakan, melepaskan), keep from harm (memelihara atau menjaga dari kejahatan, kerusakan, kerugian), heal (menyembuhkan), preserve (memelihara, menjaga, melindungi, mempertahankan). ${ }^{44}$ Melalui kasih karunia Allah, Ia memelihara, menjaga, melindungi manusia dari bahaya, melepaskan manusia dari maut, memerdekakan manusia dari perbudakan dosa. Kasih karunia juga "Untuk menjaga orang yang berada dalam bahaya kehancuran, untuk menyelamatkan dari bahaya, kerusakan." ${ }^{45}$

Setelah manusia diselamatkan, dilindung dan dipulihkan oleh Allah melalui kasih karunia-Nya, Allah ingin manusia menyadari beberapa hal, yaitu bahwa:

Pertama, keselamatan bukan hasil pekerjaan. Dalam ayat 9 "Itu bukan hasil pekerjaanmu: jangan ada orang yang memegahkan diri" dan dalam bahasa Yunaninya ouk ex ergon, ina me tis kauxesetai. Kata ergon Genitif, Plural, ${ }^{46}$ yang berarti perbuatan (yang dituntut Taurat), kerja, tugas, tindakan, perwujudan, hasil kerja, bangunan, hal.." ${ }^{47}$ Dalam ayat ini Paulus menegaskan bahwa keselamatan itu adalah pemberian Allah dan bukan dari hasil pekerjaan, bukan perbuatan baik dari manusia, atau hasil kerja semata-mata.

Kedua, jangan ada orang yang memegahkan diri. Kata kauxesetai aorist, middle, subjuntif dari kata "kaukhaomai" ${ }^{48}$ yang berarti merasa bangga, membanggakan, menyombongkan). ${ }^{49}$ Ini menggambarkan jemaat di Efesus yang masih cenderung menganggap bahwa keselamatan dihasilkan oleh perbuatan-perbuatan mereka yang tidak benar dan masih mengandalkan Taurat, dalam arti bahwa orang-orang Yahudi mengharapkan keselamatan dengan melakukan tuntutan Taurat maka akan dibenarkan oleh Allah.

Ketiga, untuk melakukan pekerjaan baik. Ayat 10 "Karena kita ini buatan Allah, diciptakan dalam Kristus Yesus untuk melakukan

\footnotetext{
${ }^{43}$ NASEC, s.v. " $\sigma \varepsilon \sigma \omega \sigma \mu \varepsilon v o l " E$-sword-the Lord With An Electronic.

${ }^{44}$ Strong's Hebrew and Greek Dictionaries, E-sword.

${ }^{45}$ Thayer Definition,E-sword-the Lord With An Electronic.

${ }^{46}$ BMG Morphology Analysis, s.v. "ergon"In Bible Works.Version 7.

${ }^{47}$ Hasan Sutanto, PerjanjianBaru Interlinear Yunani-Indonesia dan Konkordansi Perjajian Baru Jilid I (Jakarta: Lembaga Alkitab Indonesia, 2003), 312.

${ }^{48}$ BMG Morphology Analysis, s.v." kaukhaomai" In Bible Works.Version 7.

${ }^{49}$ Hasan Sutanto, Perjanjian Baru Interlinear Yuanani-Indonesia dan Konkordansi Perjajian Baru Jilid I (Jakarta: Lembaga Alkitab Indonesia, 2003), 443.
} 
pekerjaan baik, yang dipersiapkan Allah sebelumnya. Ia mau, supaya kita hidup di dalamnya" dan dalam bahasa Yunaninya autos gar esmen poiema, ktisthentes en xristo iesos epi ergois agathois ois proetoimasen ho theos ina en autois peripatesomen. ${ }^{50}$ Kata agathois dari kata "agathos" yang berarti baik, jujur, baik hati, berguna, harta. "ergois" dari kata "ergon" bentuk Dat. Plural, yang berarti duty enjoned (kewajiban, pekerjaan, perintah, suruhan), business (pekerjaan urusan), beneficent (keuntungan, faedah, manfaat), upright (tegak, adil, jujur, tulus), virtous (baik, saleh, berbudi). ${ }^{52}$

Kata "Agathois" datif, plural, dari kata "agathos" yang berarti good (baik, bagus), profitable (menguntungkan, berfaedah), generous (murah hati), upright (tegak, jujur, adil, tulus). ${ }^{53}$ Dari penjelasan ini, dapat disimpulkan bahwa: (1) Manusia yang sudah diselamatkan karena kasih karunia Allah harus melakukan segala sesuatu yang berkenan kepada Allah, yaitu perbuatan baik atau pekerjaan baik oleh karena Allah telah dahulu mengasihinya, (2) Dengan melakukan segala kehendak Allah, berarti manusia membuktikan bahwa ia adalah orang yang sudah diselamatkan oleh Allah, dan sebagai rasa syukur, ucapan terima kasihnya kepada Tuhan, ia melakukan pekerjaan baik, yang berguna dan menghasilkan hal-hal yang baik yaitu hidup dengan memuliakan Allah; (3) Ia melakukan perbuatan baik dengan dorongan hati yang tulus, jujur bahwa ia adalah ciptaan baru yang telah diselamatkan dan memiliki tugas sekaligus tanggung jawab untuk melakukan apa yang berkenan kepada Allah untuk kemuliaan Tuhan.

Jadi, yang Paulus maksudkan kepada jemaat di Efesus bahwa mereka sudah diselamatkan oleh kasih karunia dan Allah menghendaki mereka hidup dalam kasih karunia itu dengan melakukan pekerjaan baik, yang berguna dan bukan melakukan pekerjaan yang tidak baik atau perbuatan-perbuatan yang pernah mereka lakukan waktu mereka masih hidup dalam kegelapan.seperti yang tertulis dalam ayat 2.

\section{Hermeneutika Tentang Kharis Dalam Efesus 2:8}

Hermeneutika adalah interpretasi teks atau makna tertulis "Kata Hermeneutics (Bahasa Inggris), atau hermeneutik, yang berarti menginterpretasi, menjelaskan, atau menerjemahkan.. ${ }^{54}$ Penulis akan

\footnotetext{
${ }^{50}$ E-sword-the Lord With An Electronic.

${ }^{51}$ Hasan Sutanto, PerjanjianBaru Interlinear Yunani-Indonesia dan Konkordansi Perjajian Baru Jilid I (Jakarta: Lembaga Alkitab Indonesia, 2003), 2.

${ }^{52}$ The Analytical Greek Lexicon, s.v. "Ergon."

${ }^{53}$ Ibid., s.v. "Agathos"

${ }^{54}$ Hasan Sutanto, Hermeneutik: Prinsip dan Metode Penafsiran Alkitab (Malang: SAAT, 1998), 1.
} 
berusaha meneliti atau mengobservasi teks Surat Efesus 2:8 menerjemahkan dari bahasa aslinya serta menjelaskan secara spesifik.

\section{Analisa Teks Ayat 8}

Bahasa yang digunakan dalam Perjanjian Baru adalah Yunani Koine (bahasa Yunani Hellenistik atau Yunani umum, semacam bahasa yang cukup popular di Pelestina pada saat itu $)^{55}$ Dalam bahasa Yunaninya

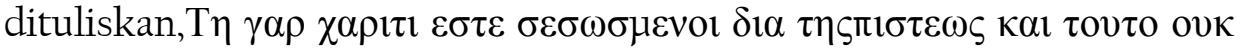

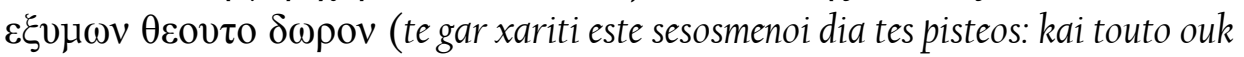
exumon, theos to doron). ${ }^{56}$

Berikut ini merupakan terjemahan yang dianggap mendekati bahasa aslinya:

Terjemahan harafiah, "Sebab kamu diselamatkan karena anugerah melalui iman, itu bukan berasal dari kamu sendiri, itu pemberian dari Allah."

Hasan Sutanto menerjemahkan, "Sebab karena anugerah kamu telah diselamatkan melalui iman; dan dalam hal ini bukan dari kamu, dari Allah itu pemberian. ${ }^{, 57}$

Jay P. Green menerjemahkan, "For by grace you are saved, through faith, and that not of your selves, (it is) the gifs of God." 58

TB: "Sebab karena kasih karunia kamu diselamatkan oleh iman; itu bukan hasil usahamu, tetapi pemberian Allah"

BSH: "Allah mengasihi kalian, itu sebabnya Ia menyelamatkan kalian karena kalian percaya kepada Yesus. Keselamatan kalian itu bukanlah hasil usahamu sendiri"

Dalam terjemahan di atas, maka penulis memberikan usulan terjemahan bagi Efesus 2:8 yaitu:

"Sebab karena ${ }^{59}$ kasih karunia ${ }^{60}$ kamu $^{61}$ telah diselamatkan ${ }^{62}$ oleh $^{63}$ iman $^{64}$ dan itu bukan ${ }^{65}$ dari ${ }^{66}$ hasil usahamu, tetapi pemberian ${ }^{67}$ Allah.." ${ }^{68}$

\footnotetext{
${ }^{55}$ Ibid., 159.

${ }^{56}$ E-sword-the Lord With An Electronic.

${ }^{57}$ Hasan Sutanto, PerjanjianBaru Interlinear Yunani-Indonesia dan KonkordansiPerjajian Baru, Jilid I (Jakarta: Lembaga Alkitab Indonesia, 2003), 92.

${ }^{58}$ Jay P. Green, The Interlinear Bible Greek/Engglish Volume IV (Michigan: Baker Book House Company, 1981), 907.

59 "gar" dapat diartikan "karena", "tetapi", "karena itu", "bahkan", "sesungguhnya". "sebab", "maka”, "lalu”, "memang”(Hasan Sutanto, PerjanjianBaru Interlinear Yunani-Indonesia dan KonkordansiPerjajian Baru, Jilid I\&II). Dalam konteks ini, kata "gar" menunjukkan bahwa kasih karunia yang menyelamatkan itu benar-benar nyata atau tidak diragukan lagi, memang sesuatu yang sungguh-sungguh terjadi atau sebuah kebenaran dan pernyataan yang dapat diterima.

60 "Xariti" noun dative, Feminine, Singular, dari kata "Kharis" berarti grace, (anugerah, pemberian, kemurahan hati, pahala, keramahan, syukur, faedah) (Hasan
} 


\section{Perbandingan Terjemahan Alkitab Untuk Kata Kharis}

iman..." 69

Sebab karena kasih karunia kamu diselamatkan oleh

$\begin{array}{ll}\text { KJV } & \text { : For by grace are ye saved through faith...." } \\ \text { ASV } & : \text { For by grace have ye been saved..." } \\ \text { BBE } & : \text { Because by grace you have salvation..." } \\ \text { DBY } & : \text { For ye are saved by grace..." } \\ \text { NIV } & \text { : For it is by grace you save been saved..." } \\ \text { LITV } & \text { :For by grace you are saved..." }\end{array}$

Dari beberapa versi terjemahan di atas, maka penulis menyimpulkan bahwa ITB, KJV, ASV, dan BBE merupakan versi yang

Sutanto, Perjanjian Baru Interlinear Yunani-Indonesia dan KonkordansiPerjajian Baru, Jilid I\&IIdan BMG Morphology, Word Analysis, In Bible Works Version 7) dengan maksud keselamatan adalah anugerah, pemberian dari Allah, kemurahan hati Allah sematamata.

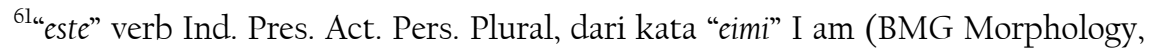
Word Analysis, In Bible Works Version 7)

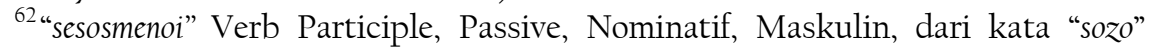
berarti to save (menyelamatkan, melindungi, menyembuhkan) (Hasan Sutanto, PerjanjianBaru Interlinear Yunani-Indonesia dan KonkordansiPerjajian Baru, Jilid IeII dan BMG Morphology, Word Analysis, In Bible Works Version 7), (Dengan maksud menyelamatkan, menolong, melindungi dari bahaya, dari kebinasaan atau dari kematian.

63“dia" Gen. Berarti through (melalui, dengan, oleh, dalam, demi, karena), (Hasan

Sutanto, PerjanjianBaru Interlinear Yunani-Indonesia dan Konkordansi Perjajian Baru, Jilid I\&II) Dalam konteks ini keselamatan diperoleh karena iman.

64 "pisteos", noun Gen. Fem. Sing, dari kata "pistis" berarti faith, belief, trust (kepercayaan, iman, kesetiaan, keyakinan,ketergantungan, ajaran yang diimani), (BMG Morphology, Word Analysis, In Bible Works Version 7).

65 "ouk" dari kata "ou" yang berarti not, no (tidak, bukan,tidak pernah, tidak bisa, jangan), (BMG Morphology, Word Analysis, In Bible Works Version 7) keselamatan tidak diperoleh bukan dari usaha atau tidak pernah melalui perbuatan manusia.

${ }^{66}$ "es" Prepotion Genitif dari kata "ek" yang berarti you (dari, berasal dari, berdasarkan, kamu sendiri),(BMG Morphology, Word Analysis, In Bible Works Version 7).Dalam konteks ini bahwa keselamatan tidak diperoleh berdasarkan perbuatan atau usaha manusia atau keselamatan tidak berasal dari usaha manusia tetapi berasal dari Allah

67“doron" yang berarti a gift (pemberian, persembahan) noun Nom. Neu. Sing.(BMG Morphology, Word Analysis, In Bible Works Version 7).

${ }^{68}$ “Theou" dari kata "Theos" berarti God. Noun Gen. Mas. SingBMG Morphology, Word Analysis, In Bible Works Version 7). Dalam kontek ini hanya Allah yang dapat memberikan keselamatan kepada manusia.

${ }^{69}$ BMG Morphology, Word Analysis, In Bible Works Version 7 
sesuai dengan tata bahasa dan LITV, DBY dan NIV merupakan versi terjemahan yang mendekati bahasa asli.

Menurut Kamus Bahasa Inggris 'Grace'adalah, "keluwesan, sifat-sifat yang menarik, doa pendek sebelum makan, kemurahan hati, kemuliaan, rahmat, kelonggaran." 70 Jadi, kasih karunia merupakan sifat Allah yang penuh dengan kemurahan hati-Nya, kemuliaan-Nya dan rahmat-Nya bagi manusia berdosa.

\section{Penggunaan Kata Kharis dalam Surat Efesus}

Dalam surat Efesus kata kharis digunakan sebanyak 12 kali yaitu:

Pertama, 1:2 "Kasih karunia dan damai sejahtera dari Allah,..." Perkataan Paulus dalam ayat ini merupakan salam pembukaan suratnya.Kasih karunia Allah yang mencakup kemurahan, kebaikan dan anugerah-Nyayang Ia berikan kepada jemaat untuk menyertai mereka.

Kedua, 1:6 "Supaya terpujilah kasih karunia-Nya yang mulia, yang dikaruniakan-Nya kepada kita di dalam Dia, yang dikasihi-Nya. Kasih karunia ini berupa kelayakan-Nya bagi manusia untuk menerima kasihNya dan dikasihi oleh Allah.

Ketiga, 1:7 “..., yaitu pengampunan dosa, menurut kekayaan kasih karunia-Nya." Paulus ingin menjelaskan bahwa penebusan dan pengampunan dosa hanya terjadi karena pekerjaan kekayaan kasih karunia Allah. Kasih karunia yang dimaksudkan Paulus di sini adalah pengampunan-Nya bagi manusia yang berdosa. Pengampunan berarti mengangkut dosa manusia dan membayar dosa manusia, membebaskan dari perhambaan dosa

Keempat, 2:5 “...oleh kasih karunia kamu diselamatkan.”Walaupun manusia terhitung sebagai manusia yang telah mati karena dosa, tetapi oleh karena kasih karunia-Nya, kemurahan-Nya manusia diselamatkan dari kematian. Kasih karunia-Nya yang menghidupkan manusia dari kematian rohani.

Kelima, 2:7 “...Ia menunjukkan kepada kita kekayaan kasih karuniaNya..." Kekayaan dari kasih karunia yang melimpah-limpah (tidak terhitung banyaknya atau melebihi dari ukuran) sesuai dengan kebaikan-Nya akan ditunjukkan oleh Allah kepada orang-orang percaya pada saat bersama-sama dengan Dia di sorga

Keenam, 2:8 "Sebab karena kasih karunia kamu diselamatkan..."Manusia diselamatkan karena kasih karunia-Nya semata-mata dan melalui iman. Kasih karunia yang dimaksud oleh Paulus di sini yaitu, kemurahan Allah, kebaikan hati Allah, hadiah dari

\footnotetext{
${ }^{70}$ Kamus Bahasa Inggris, s.v. "Grace.”
} 
Allah dalam bentuk pengampunan-Nya atas dosa manusia, penerimaanNya dan penyelamatan-Nya bagi manusia yang berdosa

Ketujuh, 3:2 "...kasih karunia Allah, yang dipercayakan kepadaku karena kamu."Kasih karunia yang dimaksudkan oleh Paulus di sini yaitu, "Kasih karunia yang diberikan Allah (oleh Kristus) kepada Paulus dalam bentuk kabar baik tetapi rahasia dan dipercayakan Allah kepada Paulus untuk diberitakan kepada orang-orang Yahudi dan bukan Yahudi.

Kedelapan, 3:7 "...aku telah menjadi pelayannya menurut pemberian kasih karunia Allah,..” Paulus mendapatkan kasih karunia yaitu kuasa, kekuatan dari Allah untuk memberitakan Injil sebagai pelayan Tuhan dengan maksud bahwa Paulus menjadi pelayan Tuhan hanya sematamata karena anugerah Allah bagi dirinya.

Kesembilan, 3:8 "Kepadaku, yang paling hina di antara segala orang kudus, telah dianugerahkan kasih karunia ini,..." Di sini Paulus menjelaskan bahwa ia "yang paling hina dan paling berdosa" ${ }^{\text {"1 }}$ tetapi karena kasih karunia Allah maka ia mendapat tugas dari Allah untuk memberitakan Injil kepada orang-orang bukan Yahudi. Allah bukan hanya membuat mereka percaya tetapi Ia membuat Injil menjadi nyata dan hal ini dapat terjadi karena kasih karunia. Kasih-Nya begitu luas dan kaya dan berlaku juga bagi orang bukan Yahudi.

Kesepuluh, 4:7 "Tetapi kepada kita masing-masing telah dianugerahkan kasih karunia menurut ukuran pemberian Kristus."Paulus menjelaskan tentang kasih karunia yang dianugerahkan oleh Allah kepada setiap jemaat menurut ukuran pemberian Kristus dan bermacam-macam karunia, dengan maksud sesuai dengan kahendakNya dan dipakai untuk kemuliaan-Nya, bukan untuk menimbulkan adanya perbedaan dalam jemaat sehingga terjadi perpecahan tetapi untuk kesatuan dalam Kristus.

\section{Penggunaan Kata Kharis dalam Kitab-kitab Lain}

Pertama, Injil Yohanes 1:17 “...tetapi kasih karunia dan kebenaran datang oleh Yesus Kristus.” Bagian ini menunjukkan hanya Yesus yang mendatangkan kasih karunia dan kebenaran bagi manusia.

\footnotetext{
${ }^{71}$ Kata "elachistoteros", yang diterjemahkan di sini dengan "yang paling hina", adalah bentuk yang tidak biasa: kita dapat menyebutnya suatu komparatif kembar atau suatu komparatif yang diperoleh dari suatu superlatif, yaitu "elachistos". Kalau dibandingkan dengan 1Kor 15:9:"ege....eimi elachistos ton apostolon" (= aku yang paling hina di antara para rasul), maka apa yang dimaksudkan dengan ungkapan di atas adalah suatu peningkatan, setingkat dengan 1 Tim 1:15: "hon (hamartolon) protos eimi ego" = di antara mereka/orang-orang berdosa akulah yang paling berdosa. (J.L.CH. Abineno,Tafsiran Surat Efesus, hal. 78).
} 
Kedua,Kisah Para Rasul 7:46 "Daud telah mendapat kasih karunia di hadapan Allah...” Bagian ini kasih karunia digambarkan sebagai anugerah kesempatan yang diberikan kepada Daud untuk mendirikan suatu tempat kediaman bagi Allah Yakub.

Ketiga, Roma 3:24 "dan oleh kasih karunia telah dibenarkan..." Bagian ini menunjukkan kasih karunia Allah melalui pengampunan-Nya, kemurahan-Nya, kebaikan-Nya telah membenarkan manusia tanpa syarat.

Keempat, Roma 6:1 “...supaya semakin bertambah kasih karunia itu? Kasih karunia akan memampukan orang percaya untuk hidup sesuai dengan kehendak Allah, bukan memanfaatkan kasih karunia berupa pengampunan-Nya untuk bebas melakukan dosa.

Jadi, kasih karunia merupakan kemurahan, anugerah-Nya yaitu Ia memberi sebuah kelayakan dan kesempatan untuk melayani Tuhan. Kekuatan dan kemampuan untuk melayani, kekuatan dalam kelemahan serta mampu menanggung beban hidup yang berat, kekuatan melakukan kehendak-Nya. Bahkan kasih karunia Allah dalam bentuk pemulihanNya bagi orang percaya untuk hidup dalam pengampunan terhadap sesama. Kasih karunia-Nya tidak akan pernah habis, senantiasa ada untuk mengampuni dan menyelamatkan manusia yang berdosa.

\section{IMPLEMENTASI KHARISTERHADAP KEHIDUPAN ORANG PERCAYA MASA KINI}

Menurut Kamus Umum Bahasa Indonesia, implementasi adalah pelaksanaan, penerapan. ${ }^{72}$ Berdasarkan definisi tersebut maka penulis akan melihat bagaimana makna kata kharis dapat diimplementasikan dalam kehidupan orang percaya masa kini di mana kata ini dikenal dengan sebutan kasih karunia.

Prinsip-prinsip dari kharis yang perlu diterapkan dalam kehidupan orang percaya masa kini berdasarkan surat Efesus 2:8, yakni:

\section{Hanya Karena Kasih Karunia Manusia Diselamatkan}

Kasih karunia adalah anugerah, pemberian dan kemurahan Allah bagi manusia.Ia menyatakan kemurahan dan kasih-Nya melalui kehadiran Yesus Kristus ke dalam dunia,mati di kayu salib untuk menebus dan menyelamatkan manusia dari hukuman dosa. Seharusnya manusiayang dihukum akibat dari dosa manusia itu sendiri, tetapi Allah yang penuh kasih dan kemurahan, Ia melakukan hal yang sangat berbeda

\footnotetext{
${ }^{72}$ Kamus Besar Bahasa Indonesia, s.v. "Implementasi".
} 
dari apa yang harus manusia terima, yaitula menyatakan kasih-Nya dan kemurahan-Nya yang besar melalui kematian Yesus Kristus bagi manusia supaya manusia memperoleh hidup yang kekal. Ia menyelamatkan manusia hanya karena anugerah-Nya semata-mata, bahkan Ia menyatakan kasih-Nya sesuai dengan kehendak-Nya, kebaikan-Nya dan kerelaan-Nya. Jadi, keselamatan adalah hanya pemberian, kemurahan, anugerah Allah semata-mata.Ada beberapa hal yang berhubungan dengan kasih karunia yang menyelamatkan manusia, yakni:

\section{Manusia Diselamatkan melalui Iman}

Keselamatan adalah kasih karunia Allah melalui iman. "Karya Kristus datang pada kita melalui kasih karunia berdasarkan iman." ${ }^{73}$ Iman berperan penting dalam karya penyelamatan Allah bagi manusia, yaitu iman kepada Yesus Kristus sebagai Tuhan dan Juruselamat dunia. Keselamatan adalah anugerah Allah, bukan berarti menyingkirkan peran iman dalam karya Allah. "Betapapun benar kenyataan bahwa kita sampai pada percaya itu hanya karena anugerah yang mendahului atau yang menyebabkannya," ${ }^{74}$ berarti manusia dapat percaya kepada Yesus Kristusdan menerima keselamatan itu hanya karena anugerah dan kemurahan Allah, bukan karena usaha manusia. Jadi, iman yang menyelamatkanadalah:

Pertama, "iman kepada Yesus Kristus adalah satu-satunya syarat yang diminta Allah untuk keselamatan. Iman bukan saja suatu pengakuan tentang Kristus, tetapi juga suatu tindakan yang terbit dari hati orang percaya (Mat 4:9)." ${ }^{75}$ Iman kepada Yesus adalah sebuah pengakuan dan harus disertai tindakan yang taat kepada Allah.

Kedua, "iman kepada Yesus Kristus sebagai Tuhan dan Juruselamat adalah tindakan sesaat dan juga sikap yang berkesinambungan yang harus bertumbuh dan harus dikuatkan (Rm 4:25). ${ }^{\text {76 }}$ Jadi, iman kepada Yesus Kristus harus tetap hidup dan selalu dikuatkan.

\section{Keselamatan Bukan Hasil Usaha Manusia}

Keselamatan bukan hasil usaha manusia. Merupakan keharusan bagi kebanyakan manusia kalau ia sedang mengerjakan sesuatu atau mengusahakan sesuatu dan ia akan berharap untuk mendapatkan hasil

\footnotetext{
${ }^{73}$ R. C. Sproul, Kebenaran-kebenaran Dasar Iman Kristen (Malang: Seminari Alkitab Asia Tenggara, 2002), 263.

${ }^{74}$ TafsiranAlkitabMasaKiniJilid 3 (Jakarta: BPK Gandum Mas, 1976), 607.

${ }^{75}$ AlkitabPenuntunHidupBerkelimpahan (Jakarta: Gandum Mas dan LAI, 1974), 1848.

${ }^{76}$ Ibid., 1848.
} 
dari pada apa yang telah ia kerjakan, tetapi R.C. Sproul mengatakan dalam bukunya bahwa:

Kasih karunia merupakan belas kasihan Allah yang diberikan bukan berdasarkan amal baik kita. Hal ini merupakan tindakan atau inisiatif Allah terhadap kita. Kasih karunia bukan merupakan substansi yang dapat mendiami jiwa-jiwa kita. Kita bertumbuh di dalam anugerah, bukan berdasarkan ukuran secara kuantitas dari substansi di dalam diri kita. Berdasarkan pertolongan dari Roh Kudus yang tinggal di dalam kita dan bertindak dengan lembut kepada kita dan atas kita. ${ }^{77}$

Penyataan di atas menunjukkan bahwa keselamatan bukan hasil usaha atau perbuatan baik manusia, bukan berdasarkan keberadaan manusia itu sendiri, melainkan hanya karena kasih karunia Allah dan melalui tindakan Roh Kudus yang lembut membuat orang percaya dapat bertumbuh di dalam anugerah-Nya. Jadi, usaha apapun yang dilakukan oleh manusia untuk mencapai keselamatan tidak akan membawa hasil. Allah tidak menyelamatkan manusia berdasarkan perbuatannya melainkan anugerah Allah semata-mata dan bukan diusahakan oleh manusia.

\section{Bukan untuk Memegahkan Diri}

Keselamatan yang dianugerahkan oleh Allah kepada mausia bukan untuk memegahkan diri. Keselamatan bukan didapat karena usaha manusia, baik usaha melakukan perintah Tuhan bahkan usaha dalam penyembahan berhala oleh orang-orang yang tidak percaya Yesus Kristus."Memegahkan diri karena berhala-berhala berarti percaya kepada berhala-berhala. Jadi kepercayaan pada diri sendiri ini (Paulus menganggap tidak lebih baik dari pada pemujaan berhala) ada lawan dari ketidakpercayaan pada diri sendiri yang menyandarkan sepenuhnya pada Allah dan rahmat-Nya." ${ }^{78}$ Orang yang percaya kepada diri sendiri bahwa ia layak diselamatkan karena ia telah melakukan kebaikan, ia sama dengan orang-orang yang terlibat langsung dalam penyembahan berhala. Ia tidak lebih baik dari orang-orang yang tidak percaya kepada Yesus Kristus. Karena hanya Yesus Kristus yang harus dipercayai sebagai Tuhan dan Juruselamat manusia, karena di luar Yesus adalah berhala-berhala.Allah menganugerahkan keselamatan kepada manusia karena Allah tahu bahwa manusia tidak akan pernah bisa mendapatkannya melalui kekuatan dirinya sendiri sebagai manusia yang lemah, penuh dengan dosa. Allah ingin supaya manusia menyadari

\footnotetext{
${ }^{77}$ R. C. Sproul, Kebenaran-kebenaran Dasar Iman Kristen (Malang: Seminari Alkitab Asia Tenggara, 2002), 263-264.

${ }^{78}$ TafsiranAlkitabMasaKinijilid 3 (Jakarta: BPK Gandum Mas, 1976), 607.
} 
bahwa keselamatan yang telah diperoleh adalah dari Dia dan merupakan suatu anugerah semata-mata .

\section{Ciri Kasih Karunia}

Jika kasih karunia merupakan anugerah Allah kepada manusia secara cuma-cuma tanpa syarat, maka kasih karunia memiliki ciri tertentu yang membedakannya dari hal yang lain. Adapun ciri dari kasih karunia-Nya adalah sebagai berikut:

\section{Kasih Karunia Tidak Layak Diterima}

"Kasih karunia merupakan belas kasihan atau kemurahan Allah bagi kita yang tidak layak kita terima." ${ }^{79}$ Pemberian kasih karunia Allah kepada manusia tidak berdasarkan atau tidak ada hubungannya dengan perbuatan baik dan keberadaan manusia. Jika manusia menganggap kasih karunia-Nya berdasarkan perbuatan baik atau berdasarkan kelayakannya, maka manusia akan kehilangan ciri dari kasih karunia Allah.Allah menunjukkan kasih-Nya kepada manusia karena manusiatelah berdosa, bukan karena manusia hidup benar di hadapan Allah. Walaupun keberadaan manusia yang berdosa, tidak layak mendapatkan kasih-Nya dan layak dihukum oleh Allah karena akibat dosa, tetapi Allah menyatakan kasih-Nya dengan menyelamatkan manusia dengan cuma-cuma.

\section{Kasih Karunia Tidak Dapat Dibeli}

Manusia bukan saja tidak layak menerima kasih karunia, tetapi tidak dapat membeli kasih karunia Allah. Ada orang yang berpikir bahwa mereka diselamatkan oleh Allah karena kasih karunia, tetapi dengan berjalannya waktu, mereka mulai menganggap bahwa perbuatan baik dan usaha mereka itu seolah-olah membayar keselamatan yang Allah telah kerjakan dalam hidup mereka. Ini suatu kekeliruan yang terjadi dalam kehidupanorang percaya. Jadi, mereka secara tidak langsung hidup dalam kasih karunia yang dapat dibeli dengan perbuatan baik atau dengan usaha. Walaupun mereka berprinsip membeli, "tetapi pada dasarnya kasih karunia tidak dapat diganti oleh apapun." 80 Jadi, apapun dan bagaimanapun bentuk usaha manusia untuk memperoleh keselamatan, semuanya akan membawa kesia-siaan saja, karena Allah tidak berkenan terhadap perbuatan baik manusia yang berusaha membeli keselamatan.

\footnotetext{
${ }^{79}$ R. C. Sproul, Kebenaran-kebenaran Dasar Iman Kristen (Malang: Seminari Alkitab Asia Tenggara, 2002), 264.

${ }^{80}$ David A. Seamands, Kesembuhan Kasih Karunia (Bandung: Yayasan Kalam Hidup, 1988), 111 .
} 


\section{Kasih Karunia Allah Tidak Bersyarat}

Jika ditinjau kembali Efesus 2:5, bahwa Allah yang kaya dengan rahmat, oleh kasih-Nya yang besar, maka Ia menyelamatkan manusia dari kematian. Hal ini menunjukkan bahwa kasih Allah yang menyelamatkan manusia tidak menuntut syarat apapun dari manusia itu sendiri. "segala aktivitas, perbuatan, hanya dari pihak yang mengasihi saja. Kasih Allah tidak disebabkan adanya sifat pada manusia, melainkan kasih ini memberi sifat yang diinginkan." ${ }^{81}$ Jadi, sepenuhnya Allah yang bertindak. Ia berkehendak memberikannya tanpa syarat. "Kasih Allah merupakan suatu aksi dan bukan reaksi terhadap manusia". Kasih-Nya tidak tergantung pada keadaan manusia, melainkan pada keberadaan Diri-Nya. Ia mengasihi manusia karena Ia adalah kasih." ${ }^{82}$

Jadi, kalau saja Ia mengasihi manusia karena keberadaan manusia itu sendiri, maka manusia yang tidak sempurna tidak akan pernah dapat memenuhi standar Allah yang begitu sempurna.

\section{Kasih Karunia Allah Tidak Terbatas}

Kasih karunia Allah melalui pemeliharaan-Nya, pertolongan-Nya, perlindungan-Nya dan berkat-Nya bagi manusia tidak terbatas. Tidak ada yang dapat membatasi kasih-Nya. "Betapa lebarnya dan panjangnya dan tingginya dan dalamnya kasih Kristus" (Efesus 3:18b). Pengetahuan yang ada pada manusia tidak dapat mengukur kasih-Nya. Ia dengan kebebasan-Nya, kehendak-Nya melimpahkan kasih-Nya bagi manusia tanpa ada yang membatasi tindakan-Nya. Perbuatan baik dan usaha manusia tidak dapat mempengaruhi Allah dalam pelimpahan kasih-Nya yang tidak terbatas.

\section{Tujuan Kasih Karunia Bagi Orang Percaya}

Setiap bagian dari rencana Allah adalah sempurna, Allah tidak pernah mengerjakan sesuatu di luar rencana-Nya, kehendak-Nya dan kuasa-Nya. Ia tidak mengerjakannya dengan serampangan, tetapi Ia adalah Allah yang sempurna sehingga apapun yang dikerjakan-Nya tidak pernah salah, tetapi tepat pada tujuan-Nya. Demikian juga dengan kasih karunia-Nya. Adapun tujuan dari kasih karunia-Nya bagi manusia, yakni:

\section{Melakukan Pekerjaan Baik}

\footnotetext{
${ }^{81}$ R. Soedarmo, Ikhtisar Dogmatika (Jakarta: BPK Gunung Mulia, 1985), 90.

${ }^{82}$ Ibid., 114.
} 
"Sesuai tujuan anugerah-Nya sendiri Allah menyelamatkan dan memanggil kita untuk hidup kudus. ${ }^{\text {"83 }}$ Allah menghendaki manusia yang sudah diselamatkan oleh kasih karunia-Nya supaya melakukan pekerjaan baik yang telah dipersiapkan oleh Allah sebelumnya, yaitu hidup dalam kekudusan. Herman Ridderson mengatakan dalam bukunya bahwa:

Salah satu konsekuensi utama dari penciptaan manusia oleh Allah adalah tanggung jawab manusia kepada Allah. Karena Allah adalah Penciptanya, maka manusia harus memuliakan dan bersyukur kepada-Nya. Hidup bukan hanya eksistensi yang Allah berikan kepada manusia, tetapi terkait dengan bagi siapakah ia hidup dan mendedikasikan hidupnya. ${ }^{84}$

Manusia adalah ciptaan Tuhan dan harus melaksanakan tanggung jawabnya hidup memuliakan Tuhan selama hidupnya. Manusia harus menyadari bahwa ia ada di dunia ini untuk mengabdikan seluruh keberadaan hidupnya bagi Allah Penciptanya. Bahkan manusia yang sudah diselamatkan oleh Allah harus hidup dalam perbuatan baik untuk kemuliaan Allah. Perbuatan baik itu bukan semata-mata untuk membayar keselamatan melainkan respon dari mereka yang sudah diselamatkan. Allah menghendaki hidup orang percaya harus berpadanan dengan kasih-Nya. Bukan semata-mata berhutang dan hendak membayar kasih Allah, tetapi merupakan ungkapan syukur atas kasih Allah. Keselamatan adalah anugerah Allah, tetapi Allah ingin orang yang sudah mengalami keselamatan membagi-bagikan kasih kepada orang lain dengan memberitakan keselamatan yang telah diperoleh dari Allah secara cuma-cuma, supaya orang lain turut mengalami kasih Allah yang menyelamatkan. Allah ingin manusia kembali hidup dalam kekudusan yaitu dengan melakukan pekerjaan baik dan tidak diperhamba oleh dosa. Paul G. Caram mengatakan di dalam bukunya:

Kasih karunia tidak berarti membolehkan segala sesuatu. Dengan diberikannya kasih karunia, itu tidak berarti dosa diperbolehkan ataupun dimaklumi. Kasih karunia itu bukan berarti Allah memalingkan wajah-Nya dan berpura-pura tidak melihat dosa kita, atau karena mengetahui kelemahan moral kita Ia memaklumi ketidaktaatan kita. Kasih karunia tidak pernah menghilangkan tanggung jawab kita untuk memelihara perintah-perintah Allah, sebaliknya memberdayakan kita untuk menaati semua itu. Gereja

\footnotetext{
${ }^{83}$ J. Knox Chamblin, Paulus dan Diri Ajaran Rasuli Bagi Keutuhan Pribadi (Surabaya: Momentum, 2009), 57.

${ }^{84}$ HermanRidderbos,Paulus Pemikiran Utama Theologinya (Surabaya: Momentum Christian Literature, 2008), 102.
} 
harus menyadari bahwa Allah memang mengampuni dosa-dosa kita dengan dara Yesus, tetapi Ia tidak menganggap enteng dosa-dosa kita. Sebaliknya, Ia menawarkan zat ilahi yang dinamakan kasih karunia ini sehingga kita dibebaskan dari cengkeraman dosa sehingga kita bisa melakukan kehendak Allah. Di mana dosa berlimpah, di situ kasih karunia dapat tersedia lebih berlimpah (Roma 5:20b). ${ }^{85}$

Penyataan di atas dengan jelas menunjukkan bahwa kasih karunia yang diberikan oleh Allah kepadamanusia melalui pengampunan-Nya bukan untuk memberi kesempatan kepada manusia terus-menerus bertekun dalam dosa, melainkan memberi kuasa kepada manusia untuk hidup melakukan kehendak Allah.

\section{Kuasa Untuk Melayani Tuhan}

Orang yang sudah mengalami kasih karunia Allah akan diberikan kuasa melalui Roh Kudus untuk melayani Tuhan, karena keselamatan yang dianugerahkan bukan untuk dinikmati sendiri oleh manusia. Tujuan keselamatan orang percaya adalah untuk melayani Allah dan membagikan keselamatan itu kepada orang lain. Panggilan untuk keselamatan disertai hak dan tanggung jawab untuk memelihara iman dan menyebarkan berita kesukaan bagi mereka yang belum mengenal Kristus." ${ }^{86}$ Orang yang telah mengalami kasih karunia harus memberitakan Injil kepada orang lain dan Kuasa Roh Kudus yang memberi kemampuan serta menjadikan pelayanan berhasil untuk kemuliaan Allah.

\section{Kuasa Untuk Melakukan Kehendak Allah}

Di dalam Alkitab Penuntun tertulis:

Mereka yang menjadi ciptaan baru di dalam Kristus menerima kasih karunia terus-menerus untuk menjalani kehidupan Kristen, menolak dosa dan melayani Allah. Orang percaya berjuang untuk hidup bagi Allah oleh kasih karunia-Nya yang bekerja di dalam mereka. Kasih karunia Allah berkerja dalam orang percaya yang sungguh-sungguh, hingga mereka rela dan bertindak menurut maksud baik Allah. ${ }^{87}$

Melalui pernyataan di atas dapat disimpulkan bahwa:

Pertama, manusia yang sudah mengalami kasih karunia Allah, yang sudah diselamatkan merupakan ciptaan baru dalam Kristus dan memperoleh kuasa dari Allah melalui Roh Kudus untuk hidup dalam kekudusan, hidup menolak dosa dan menang terhadap setiap godaan

\footnotetext{
${ }^{85}$ Paul Caram, Kekristenan Sejati (Jakarta Barat: Voice Of Hope, 2002), 49.

${ }^{86}$ Ruth Selan, Pembinaan Warga Jemaat (Bandung: Kalam Hidup, 1994), 24.

${ }^{87}$ Alkitab Penuntun Hidup Berkelimpahan ( Jakarta: Gandum Mas dan LAI, 1974),
} 
dosa. Kuasa Roh Kudus yang memberdayakan orang percaya hidup menurut standar Allah, yaitu taat akan Firman-Nya.

Kedua, orang yang sudah diselamatkan oleh kasih karunia Allah akan berjuang hidup bagi Allah. Mereka tidak lagi hidup menurut kepentingan atau keinginan daging, tetapi cenderung hidup dalam kekudusan dan semuanya semata-matabagi kemuliaan Allah.

Ketiga, kasih karunia yang Allah berikan kepada manusia bukan kesempatan untuk melakukan dosa, bukan hidup dalam kesia-sian, tetapi memberdayakan manusia hidup melakukan hal-hal yang bermanfaat dan hidup dalam kekudusan. Kekuatan yang ada pada manusia tidak akan pernah dapat hidup dalam kekudusan, tetapi kuasa Allah yang ada dalam mereka memberi kekuatan dalam menjalani hidup kudus.

Keempat, kasih karunia Allah akan tetap bekerja di dalam diri orang percaya yang sungguh-sungguh, sehingga mereka rela dipimpin oleh Allah untuk bertindak sesuai dengan maksud baik Allah atau rencana Allah.

\section{Memberi Kekuatan Menghadapi Masalah}

Kasih karunia Allah bukan saja memampukan orang percaya untuk menang atas dosa, hidup dalam kekudusan, melayani Tuhan dan hidup bagi Allah, tetapi kasih karunia Allah selalu memberi kekuatan dalam setiap masalah. Dalam Alkitab Penuntun Hidup Berkelimpahan mencatat bahwa:

Kasih karunia adalah kehadiran, kemurahan, dan Kuasa Allah. Ini merupakan suatu daya, suatu kekuatan sorgawi yang dikaruniakan kepada mereka yang berseru kepada Allah. Kasih karunia ini akan berdiam dalam diri orang percaya yang setia, yang mengalami kelemahan dan kesukaran demi Injil (Filp. 4:13). Semakin besar kelemahan dan pencobaan kita karena Kristus, semakin besar kasih karunia yang akan diberikan Allah untuk melaksanakan kehendakNya. Kita harus bangga dan melihat nilai kekal dalam kelemahan kita, dengan demikian Kuasa Kristus ada bersama-sama kita dan diam dalam diri kita sementara kita menempuh hidup ini menuju ke rumah sorgawi kita ${ }^{88}$

Jadi, dalam setiap masalah dan kelemahan yang dialami oleh orang percaya baik masalah secara jasmani maupun rohani mempunyai nilai yang berharga karena Allah bertujuan untuk menunjukkan bahwa Ia selalu mengasihi, menyertai dan memberi kekuatan dalam setiap kelemahan dan masalah. Allah ingin manusia tahu kekurangan, ketidakmampuan, dan ketidakberdayaan yang ada pada mereka sehingga

${ }^{88}$ Ibid., 1937. 
mereka dapat mengenal Allah yang penuh kuasa, kasih dan rahmat. Ia tahu persis kelemahan dan masalah setiap manusia, tetapi tatkala manusiaberseru dan berharap kepada Dia,maka Allah akan melimpahkan kemurahan-Nya dengan memulihkan hidup mereka.

\section{PENUTUP}

\section{Kesimpulan}

Berdasarkan hasil uraian penulis dalam karya ilmiah tentang makna kata kharis berdasarkan Efesus 2:8 dan implementasinya dalam kehidupan orang percaya masa kini, maka penulis dapat menarik kesimpulan sebagai berikut:

Pertama, kasih karunia adalah kehadiran Allah melalui Yesus Kristus ke dalam dunia, mati untuk menyelamatkan manusia, Ia bangkit dari kematian untuk memberi kemenangan bagi orang percaya dan Ia menyediakan tempat di sorga bagi orang yang percaya kepada-Nya.

Kedua, kasih karunia merupakan anugerah keselamatan yang dianugerahkan oleh Allah secara cuma-cuma kepada manusia berdosa yang seharusnya dihukum dan dimurkai oleh Allah. Kasih karunia-Nya dilimpahkan secara gratis tanpa membayar atau membeli dari pihak manusia. Kasih karunia Allah tidak bersyarat, tidak dibeli dan tidak dibayar oleh manusia. Ia melimpahkan kasih-Nya sesuai dengan kehendak-Nya, kerelaan-Nya dan rencana-Nya.

Ketiga, kasih karunia merupakan kemerdekaan yang Allah berikan bagi manusia atas dosa, melepaskan dari kuasa iblis, memulihkan manusia untuk kembali bersekutu dengan Allah.

Keempat, kasih karunia Allah merupakan pengampunan-Nya bagi orang berdosa yang datang bertobat kepada-Nya dengan sungguhsungguh. Pengampunan-Nya selalu ada tetapi Allah melimpahkan kasih karunia pengampunan bagi manusia bukan kesempatan untuk terus berbuat dosa.

Kelima, kasih karunia adalah kuasa Allah melalui kehadiran Roh Kudus yang memberdayakan setiap orang percaya untuk melawan godaan dosa, melakukan kehendak Allah, hidup dalam kekudusan dan memberi kemampuan melayani Tuhan serta menghadapi setiap masalah.

\section{Saran-Saran}

Dengan selesainya karya ilmiah ini, penulis memberikan beberapa saran kepada orang percaya dan secara khusus kepada pembaca karya ilmiah ini. Adapun saran-saran yang dapat penulis berikan adalah sebagai berikut: Pertama, mengingat keterbatasan penulis dalam penulisan karya ilmiah ini, maka penulis mengharapkan supaya penulis berikutnya yang akan meneliti tentang kata kharis dapat mengumpulkan 
bahan lebih banyak lagi dan lebih teliti dan analitis dalam proses penganalisaan. Kedua, hendaknya setiap orang percaya mengimplementasikan makna kharis dalam kehidupannya sehari-hari sebagai anak-anak Tuhan.

\section{KEPUSTAKAAN}

Alkitab

Alkitab, Jakarta: Lembaga Alkitab Indonesia, 2008.

Alkitab Penuntun Hidup Berkelimpahan. Malang: Gandum Mas, 1974.

Alkitab Elektronik 2.0.0- Alkitab Terjemahan Baru 1974. Jakarta: Lembaga Alkitab Indonesia.

Bible Works Version 7. e-sword-the sword of the Lord with an electronic.

Sutanto, Hasan. Perjanjian Baru Interlinear Yunani-Indonesia dan Konkordansi Perjanjian Baru, Jilid I dan II. Jakarta: Lembaga Alkitab Indonesia, 2002.

\section{Kamus}

Kamus Besar Bahasa Indonesia. Jakarta: Balai Pustaka, 1994.

The Analytical Greek Lexicon. New York.

\section{Ensiklopedi}

Ensiklopedi Alkitab Masa Kini Jilid l. Jakarta: Yayasan Komunikasi Bina Kasih, 1992.

Ensiklopedi Alkitab Masa Kini Jilid II. Jakarta: Yayasan Komunikasi Bina Kasih, 1995.

Buku-Buku

Abineno, J.L. Ch. Tafsiran Surat Efesus. Bandung: BPK, 1971.

Bakker, Anton. Ajaran Iman Katolik 2. Yogyakarta: Kanisius, 1988.

Barclay, William. Pemahaman Alkitab Setiap Hari Galatia-Efesus. Jakarta: BPK Gunung Mulia,1983.

Brill, J. Wesley. Surat-surat Kepada Ketujuh Jemaat. Bandung: Kalam Hidup,1970.

Bruce, Narromore dan Counts Bill. Bebas Dari Rasa Bersalah. Jakarta: BPK Gunung Mulia, 1974.

Caram, Paul. Kekristenan Sejati. Jakarta Barat: Voice Of Hope, 2002.

Chamblin, J. Knox. Paulus dan Diri Ajaran Rasuli Bagi Keutuhan Pribadi. Surabaya: Momentum, 2009.

Chapman, Adina. Pengantar Perjanjian Baru. Bandung: Kalam Hidup, 1980. 
Dunnett, Walter M. Pengantar Perjanjian Baru. Malang: Gandum Mas, 1960.

Griffin David, Ray. Tuhan Dan Agama Dalam Dunia Posmodern. Yogyakarta: Kanisius, 2006.

Jaffray R.A. Tafsiran Surat Rasul Paulus kepada Orang Efesus. Makassar: Yayasan Kalam Hidup, nd.

Nawawi, Hadari dan Martini Hadari. Instrumen Penelitian Bidang Sosial. Yogyakarta: Gajah Mada University Press, 1992.

Packer, J.L. Dunia Perjanjian Baru (Surabaya: Yakin dan Gunung Mas, 1995.

Ridderbos, Herman. Paulus Pemikiran Utama Theologinya. Surabaya: Momentum Christian Literature, 2008.

Rienecker, Fritz. A Linguistic Key To The Greek New Testament, Vol. 2, Romans Revelation. Grand Rapids Michigan: Zondervan Publishing House, 1980.

Seamands, A. David. Kesembuhan Kasih Karunia. Bandung: Yayasan Kalam Hidup, 1988.

Selan, Ruth. Pembinaan Warga Jemaat. Bandung: Kalam Hidup, 1994.

Soedarmo, R. Ikhtisar Dogmatika. Jakarta: BPK Gunung Mulia, 1985.

Sutanto, Hasan. Hermeneutik: Prinsip dan Metode Penafsiran Alkitab. Malang: SAAT, 1998.

Sproul, R. C. Kebenaran-kebenaran Dasar Iman Kristen. Malang: Seminari Alkitab Asia Tenggara, 2002.

Stott, John R. W. Bagaimana Pandangan Kristus Akan Gereja. Malang: SAAT, 1990.

Tafsiran Alkitab Masa Kini, Jilid 3. Jakarta: BPK Gunung Mulia, 1983.

Tenney, Merrill C. Survei Perjanjuian Baru. Malang: Gandum Mas, 1999.

Thissen, Henry. C. Theologi Sistematika. Malang: Gandum M 